\title{
積分モデルによる三次元表層密度噴流の解析 \\ NEAR FIELD ANALYSIS OF THREE-DIMENSIONAL BUOYANT SURFACE JET USING INTEGRAL FORMULATION
}

\author{
室田 明*.中过啓二**・柴垣雄一***
}

By Akira MUROTA, Keiji NAKATSUJI and Yuichi SHIBAGAKI

\begin{abstract}
A three-dimensional integral model for predicting the near field behaviour of a buoyant surface jet has been formulated and examined. It was necessary to make several assumptions based on experimental knowledges; (i) all cross-sectional velocity and buoyancy profiles are similar, (ii) the vertical entrainment is reduced by means of the stratification, and (iii) the lateral spread due to buoyancy alone is specified in terms of the spreading velocity of density front. The predicted results are found to agree fairly with experimental data. Furthermore, various integral model tests were performed by comparison with field data at Point Beach plants. It indicates that this present model is superior to another published integral models.
\end{abstract}

\section{1. 緒言}

近年, 発電施設の大容量化や集中立地に伴い, 沿岸海 域に放流される温排水量は大量となり, 対象海域の生物 環境に影響を与えることが予想される.このような大規 模な温排水の拡散現象の実態, あるいはその影響範囲の 事前予測法に関しては数多く研究されてきたけれども, 十分な解明が得られているわけではない.

温排水あるいは河川流出水が海域に放出された場合ど のような拡散挙動を呈するのか, またそれに対していか なる物理要因が影響を及ぼすのかといった問題に対し て, 著者らは基礎的な実験 ${ }^{1121 を}$ を行い, またその流動形 態について理論的な解析 ${ }^{3)}$ 試みてきた。本研究では, それらの成果を基礎に積分モデルによる予測法を提案 し, 実験および実測結果との比較より予測法の適合性を 検討する.

なお, 数值解析結果の一部はすでに第 28 回水理講演 会論文集に発表済みであるが, 本論文は理論展開の基本 的な考え方ならびに誘導過程を詳述するとともに, 現地

\footnotetext{
* 正会員 工博 大阪大学教授 工学部土木工学科 ( ₹565 吹田市山田丘 2-1)

** 正会員 工修 大阪大学講師 工学部土木工学科 (同上)

*** 学生会員 大阪大学大学院工学研究科前期課程学生(同上)
}

実測結果との比較を追加して内容を充実させたものであ る.

\section{2. 既往の櫴分モデルの総括}

近接領域における表層密度噴流の予測に対して，積分 モデルは最も広く用いられてきた予測法である.その理 由は,この手法が数值計算法に比べてより簡単化された ものであり，また古典的な噴流理論の取扱いと同様で， 均質噴流においてかなりの好結果をあげていることによ る.しかしながら，実際には積分モデルは㬰験あるいは 実測結果との比較において良好な結果をもたらすことは 少ない.それは，積分モデルはあらゆる状況に適用でき るように拡張されてきたが, 密度流特有の現象を付加条 件として与えざるを得なく，そのための実験的知見が欠 如していることも原因している.しかしながら，現象の 理解に基づいた適切な修正を均質噴流の理論展開に付け 加えることができるならば, 近接領域の流動特性に対し ては少なくとも信頼できる予測が可能となるものと考え られる。

積分モデルに関してすでに数多くの予測モデルが提案 されている. それらの適合性について実測結果との詳細 な比較検討を行ったものに, Argonne 国立研究所の 900 頁に及ぶ膨大な報告 '`がある. 積分モデルの多くは周囲 
環境水の流れや乱れ，表層熱収支等の種々の要因を含ん だ解析も行っているが, 浮力効果の表現法に焦点を絞っ て積分モデルを大別すると表一1のようになる.

浮力による第一の効果は鉛直方向乱流輸送率の低下, 換言すれば，下層からの連行量の低減である．MotzBenedict ${ }^{5}$ ' は下層からの連行を無視した二次元平面噴流 によるモデルを提唱した。 また，Pritchard ${ }^{6}$ は観測に基 づいて, 連行の生じる領域は噴流水深が 10 15 フィ一 卜に達するまでであり，それ以降は二次元平面的に振舞 うという疑似三次元モデルを提唱している．彼のモデル が連行加入量を成層度の指標であるリチャードソン数 $R i$ 之は無関係に算出しているにもかかわらず，他のモ デルに増して実測結果を精度よく予測するのは現地調査 に基づいた現象論的手法であるからであろう。他のモゔ ルの多くは, 連行速度の低減をEllison・Turner r $^{7}$ 流に $R i$ の関数として表現することにより考慮している.

浮力の第二の効果は, 密度差に基づく静水圧力の流下 方向および横方向公配により, 流れの水平方向の拡がり を促進することである。流下方向圧力勾配はStefan ・ Vaidyaraman ${ }^{8 !}$ のモデルを除いて流下方向の運動量保存 式に付加されている. 問題は横方向拡がり率 $d B / d x$ の 増大をどのように取り扱うかである。Stefan・ Vaidyaraman, Prych" ${ }^{9 \prime}$ Shirazi ・ Davis ${ }^{10 !}$ あるいは Stolzenbach・Harleman"1! によるモデルはいずれも $d B$ $/ d x$ を均質噴流の乱机による拡がり率と浮力に原因す る拡がり率との和として，次のように記述している。

$$
\frac{d B}{d x}=\left(\frac{d B}{d x}\right)_{n b}+\left(\frac{d B}{d x}\right)_{b}
$$

ここに，添字 $n b$ および $b$ はそれぞれ浮力効果のない 場合之浮力のみの場合を示す. Prych らは水表面上の油 の拡がりにみられる密度流塊の拡がり速度を用いて, $(d B / d x)_{b}$ を密度フルード数 $F d(=1 / \sqrt{R i})$ の関数之 して值接的に表現する方法を提案している。これに対し て, Stolzenbach · Harleman は, 局所的な横方向流速 は横方向密度勾配 $d \Delta \rho / d y$ と流下方向代表流速に比例
すると仮定して，横方向運動方程式を積分することによ り $(d B / d x)_{b}$ を求めている.いずれにしても, 最終的 には $(d B / d x)_{b}$ は次のような関数形で表垷される.

$$
\left(\frac{d B}{d x}\right)_{b}=\text { func }(F d, B, H)
$$

ここに，B, $H$ は噴流の代表幅および代表水深を示す.

これに対して, 林・有时 ${ }^{12)} や$ 椿・小松 ${ }^{(3)}$ のモデルは横 方向運動方程式を直接的に導入する方法である。そのた めには，横方向流速 $V$ の相似分布形を仮定し，連続方 程式を断面積分して $V$ を求める必要がある。しかも横 方向運動方程式の積分形は水平方向連行係数 $E_{h}$ に関係 した式となるので，未知数に対する基礎方程式の数の不 足は補充できない，そこで，林・有田は流下方向運動方 程式の $x$ 軸まわりの二次モーメント式を，また椿・小 松は平均流エネルギー式を導入して連立させている．基 礎方程式の構成からいえば, Prych らのモデルと比較し て理にかなった解析法であるが，あらゆる基礎方程式を 断面内積分表示するという方法によって局所的な流動特 性を適切に評価し得ているかは疑問である。

浮力効果の表現法として興味深いものに Engelund · Pederson ${ }^{14}$ のモデルがある．それは密度欠損に基でく 水面上昇に起因方る横方向圧力勾配を直接的に評価して いる．ただ，鉛直方向に積分して平面二次元問題として 解かれている点に物足りなさがあるが，測定が不可能な ほゼの僅少な水面の盛り上りであっても密度噴流の挙動 に少なからず影響を及ぼしているという指摘は重要であ ろう。

以上の総括に示されたように，積分モデルにおいては 下層からの連行の抑制と表裏の関係にある水平方向の拡 がりの促進を適切かつ簡潔に評価した理論展開が望まれ る。それはわずかな水面の盛り上りにみられるように放 流口近傍に局在する現象であり，自己保存性ならびに流 下方向保存式に基盤を置く概括的な積分モデルにおいて はもっぱら水理実験に基づいた現象の理解に頼らざるを 得ない.

\begin{tabular}{|c|c|c|c|c|c|c|c|}
\hline \multirow{2}{*}{ 提 } & \multirow{2}{*}{ 案 } & \multirow{2}{*}{ 次元 } & \multirow{2}{*}{ 基 䃈 方 程 式 } & \multicolumn{2}{|c|}{ 水面上昇量 } & \multirow{2}{*}{ 連 行 量 } & \multirow{2}{*}{ 末 知 量 } \\
\hline & & & & 圧力項 & 横方向执大 & & \\
\hline \multicolumn{2}{|c|}{ Motz-Benedict } & 2 & $C, S, M_{x}$ & - & - & $E_{n}$ & $U, \Delta \rho . B$ \\
\hline \multicolumn{2}{|c|}{ Pritchard } & 疑似 3 & $C, S$ & - & - & 成層界面 & $U, \Delta \rho$ \\
\hline \multicolumn{2}{|c|}{ Stefan-Vaidyaraman } & 3 & $C, S, M_{r}$ & - & density front & $E_{n}, E_{v}(R i)$ & $U, \Delta \rho, B, H$ \\
\hline \multicolumn{2}{|l|}{ Prych } & 3 & $C, S, M_{x}$ & $M_{x}$ & density front & $E_{h}, E_{v}(R i)$ & $U, \Delta \rho, B, H$ \\
\hline \multicolumn{2}{|c|}{ Shirazi-Davis } & 3 & $C, S, M_{x}$ & $M_{x}$ & density front & $E_{h}, E_{v}(R i)$ & $U, \Delta \rho, B, H$ \\
\hline \multicolumn{2}{|c|}{ Stolzenbach-Harleman } & 3 & $C, S, M_{x}, M_{y}$ & $M_{x}$ & $v \sim u \cdot \partial \Delta \rho / \partial y$ & $E_{h}, E_{v}(R i)$ & $U, A \rho, B, H$ \\
\hline \multicolumn{2}{|c|}{ 林·有 田 } & 3 & $C, S, M_{x}, M_{y}, M^{\prime}$ & $M_{x}$ & $v=f(\zeta)$ & $E_{v}(R i)$ & $U, \Delta \rho, B, H, E_{n}$ \\
\hline \multicolumn{2}{|c|}{ 椿 - 小松 } & 3 & $C, S, M_{r}, M_{v}, E$ & $M_{x}$ & $v=f(\zeta)$ & $E_{v}(R i)$ & $U, \Delta \rho, B, H, E_{n}$ \\
\hline
\end{tabular}

\section{表一1 既往の積分モデルの比較}

ここに, $C:$ 流量保存式, $S:$ スカラー量保存式, $M_{x}: x$ 方向運動方程式, $M_{y}: y$ 方向運動方程式, $M^{\prime}: x$ 方向運動 方程式の二次モーメント式， $E: x$ 方向エネルギー方程式 


\section{3. 基礎方程式}

\section{（1） いくつかの実験による予察}

三次元表層密度噴流の水理実験 ${ }^{1}$ から理論展開に有用 な知見を整理すれば，次のようである.

a）噴流軸に直交する各断面での流下方向流速 $U$ お よび密度差 $\Delta \rho$ の分布形状は相似性を仮定して次式のよ うにガウス分布で近似できる.

$$
\left.\begin{array}{c}
U(x, y, z)=U_{s}(x) \cdot f_{1}\left(y / B_{e}\right) \cdot f_{1}\left(z / H_{e}\right) \\
\Delta \rho(x, y, z)=\Delta \rho_{s}(x) \cdot f_{2}\left(y / B_{e}\right) \cdot f_{2}\left(z / H_{e}\right)
\end{array}\right\}
$$

ここに,

$$
f_{1}(t)=\exp \left(-t^{2}\right), f_{2}(t)=\exp \left(-t^{2} / 2\right)
$$

$U_{s}, \Delta \rho_{s}$ は水表面での軸上流速および密度差を，また $B_{e}$ と $H_{e}$ は, 流速が $U_{s}$ の $1.0 / e(=0.3679)$ となる噴 流幅および噴流水深を示す.

b) 連行速度の概念の導入により表層密度噴流への 連行量の算定が可能である. その結果, 鉛直方向連行は 放流口近傍に限定されており，放流口から離れるに従っ て平面噴流に類似した混合形態に遷移してゆく.

c）均質の表層噴流と異なり, 表層密度噴流では横方 向からの強い連行が放流口近傍から観察される. そのと きの連行速度は噴流内縁の拡がり率と線形関係にあり, 密度フルード数の関数で表示できる.

d）また, 噴流内縁の拡がりは水表面に連続流出し た油の拡がりにみられる密度流塊の拡がり速度により記 述できる。

以上の実験的予察に基づいて, 相似分布形（式（3), (4)）を基礎に積分モデルを展開するが, 提案モデルの 基本的な考え方は以下のとおりである.

（１）浮力効果は鉛直方向連行量の低減と横方向拡が りの促進の 2 つの形態に現われる.

(ii ) 鉛直方向連行係数はEllison・Turner 流に密度 フルード数の関数として表現する.

（iii）横方向連行には浮力による直接的な影響はほよ んよ゙ないと考え, 連行係数は均質噴流の值を採用する.

（iv）ただし, 横方向拡がりには横方向圧力勾配によ る移流効果が有効に働く. 拡がり率は密度流塊の拡がり 速度を用いて, 密度フルード数の関数で与えられる.

（v）したがって, 噴流の乱れによる連行は連行係数 に含まれるものと考える.

\section{（2）流下方向保存式の誘道}

座標系を図一1のようにとり，表層放流された密度噴 流が定常・非圧縮の乱流であり, 境界層近似ならびに静 水圧近似が成立するものとすると, 基礎方程式は以下の ように表わされる.

$$
\frac{\partial U}{\partial x}+\frac{\partial V}{\partial y}+\frac{\partial W}{\partial z}=0
$$
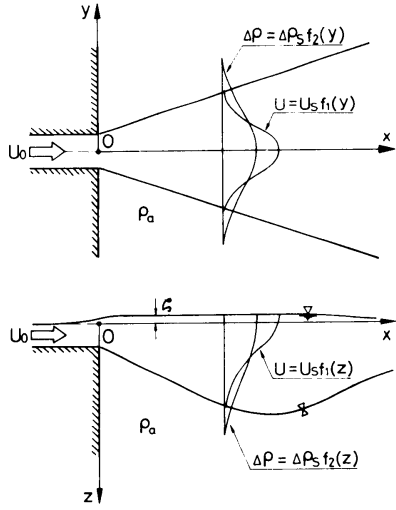

図一1座標系の説明図

$$
\begin{aligned}
& \frac{\partial}{\partial x}\left(\rho U^{2}\right)+\frac{\partial}{\partial y}(\rho U V)+\frac{\partial}{\partial z}(\rho U W) \\
& =-\frac{\partial P}{\partial x}+\frac{\partial}{\partial y}(-\overline{\rho u v})+\frac{\partial}{\partial z}(-\overline{\rho u w}) \\
& \frac{\partial}{\partial x}(U \cdot \Delta \rho)+\frac{\partial}{\partial y}(V \cdot \Delta \rho)+\frac{\partial}{\partial z}(W \cdot \Delta \rho) \\
& =\frac{\partial}{\partial y}(-\overline{\rho v})+\frac{\partial}{\partial z}(-\overline{\rho w}) \text {. }
\end{aligned}
$$

ここに, $U, V, W$ は $x, y, z$ 方向の平均流速, $\Delta \rho$ は密度差 $\left(\Delta \rho \equiv \rho_{a}-\rho, \rho_{a}\right.$ : 周囲環境水の密度 $), P$ は 圧力, $g$ は重力加速度である. また, 小文字は平均値か らの変動成分, “一”は時間平均を表わす.

圧力 $P$ は静水圧近似に基づいて以下の上うに求める. すなわち, 密度差により生じる水面上昇量をととし, 水面の盛り上り部の密度が $z=0$ における密度と等しい と仮定すると, 密度 $\rho(x, y, z)$ は次式で近似できる.

$$
\rho(x, y, z)=\left\{\begin{array}{l}
\rho_{a}-\Delta \rho_{s}(x) \cdot f_{2}\left(y / B_{e}\right) \quad:-\zeta<z<0 \\
\rho_{a}-\Delta \rho_{s}(x) \cdot f_{2}\left(y / B_{e}\right) \cdot f_{2}\left(z / H_{e}\right): 0 \leqq z
\end{array}\right.
$$

圧力は静水珐であるから

$$
\begin{aligned}
P= & \int_{-5}^{z} \rho g d z=\int_{-5}^{0} \rho g d z+\int_{0}^{z} \rho g d z \\
= & \left\{\rho_{a}-\Delta \rho_{s} \cdot f_{2}\left(y / B_{e}\right)\right\} g \zeta+\rho_{a} g z \\
& -\Delta \rho_{s} \cdot f_{2}\left(y / B_{e}\right) \cdot g \int_{0}^{z} f_{2}\left(z / H_{e}\right) d z
\end{aligned}
$$

となる. $z=\infty$ で $\partial P / \partial x=0, \partial P / \partial y=0$ であること を考慮すると, 上式より

$$
\begin{aligned}
\left\{\rho_{a}-\Delta \rho_{s} \cdot f_{2}\left(y / B_{e}\right)\right\} g \cdot \zeta \\
\quad=\Delta \rho_{s} \cdot f_{2}\left(y / B_{e}\right) \cdot g \cdot \int_{0}^{\infty} f_{2}\left(z / H_{e}\right) d z
\end{aligned}
$$

の関係が求まる.また, $\int_{0}^{\infty} f_{2}\left(z / H_{e}\right) d z=\sqrt{\pi / 2} \cdot H_{e}$ で あることから, 水面上昇量 $\zeta$ は式 $(10)$ より次式となる.

$$
\zeta(x, y)=\frac{\Delta \rho_{s}(x) \cdot f_{2}\left(y / B_{e}\right)}{\rho_{a}-\Delta \rho_{s}(x) \cdot f_{2}\left(y / B_{e}\right)} \frac{\sqrt{2 \pi}}{2} H_{e}
$$


式（11）を式（9）に代入して $x$ で微分すれば, 式 (6) 中の流下方向圧力勾配が次のように求まる.

$$
\begin{aligned}
\frac{\partial P}{\partial x}= & \frac{\sqrt{2 \pi}}{2} g \frac{\partial}{\partial x}\left\{\Delta \rho_{s} \cdot f_{2}\left(y / B_{e}\right) \cdot H_{e}\right\} \\
& -g \frac{\partial}{\partial x}\left\{\Delta \rho_{s} \cdot f_{2}\left(y / B_{e}\right) \int_{0}^{z} f_{2}\left(z / H_{e}\right) d z\right\}
\end{aligned}
$$

分布形の相似関数表示式（3)，(4) および式 (12) を基礎方程式（ 5 ) （ 7 ） に代入して, $z=0 \sim \infty, y=$ $-\infty \sim \infty$ の範囲で積分すると, 次の方程式群を得る.

$$
\begin{aligned}
& I_{1} I_{2} \frac{d}{d x}\left(U_{s} B_{e} H_{e}\right) \\
& =\left(2 I_{2} E_{h} H_{e}+I_{1} E_{v} B_{e}\right) U_{s} \\
& I_{3} I_{4} \frac{d}{d x}\left(\rho_{a} U_{s}^{2} B_{e} H_{e}\right)-I_{5} I_{6} \frac{d}{d x}\left(\Delta \rho_{s} U_{s}^{2} B_{e} H_{e}\right) \\
& =-I_{7} \frac{d}{d x}\left(\Delta \rho_{s} g B_{e} H_{e}^{2}\right) \\
& \frac{d}{d x}\left(\Delta \rho_{s} U_{s} B_{e} H_{e}\right)=0
\end{aligned}
$$

上式はそれぞれ流量, 浮力流束および運動量の流下方向 保存式である. 式 (13) 中の $E_{h}, E_{v}$ はそれぞれ横方向 および鉛直方向の連行係数であり, 連行速度 $W_{e}$ と $V_{e}$ は次式で定義される。

$$
\left.\begin{array}{l}
W_{e}(x, y)=E_{v} \cdot U_{s} \cdot f_{1}\left(y / B_{e}\right) \\
V_{e}(x, z)=E_{h} \cdot U_{s} \cdot f_{1}\left(z / H_{e}\right)
\end{array}\right\}
$$

式 (13) （15）を項別微分して整理すると, 最終的に次 の連立一階常微分方程式系を得る.

$$
\begin{aligned}
\frac{d U_{s}}{d x}= & \frac{U_{s}}{\left(I_{3} I_{4} F d_{s}^{2}-I_{5} I_{6} F_{s}{ }^{2}-2 I_{7}\right)}\left\{I_{7} \frac{1}{B_{e}} \frac{d B_{e}}{d x}\right. \\
& \left.-\left(I_{3} I_{4} F d_{s}^{2}+I_{7}\right)\left(\frac{2 E_{h}}{I_{1} B_{e}}+\frac{E_{v}}{I_{2} H_{e}}\right)\right\} \ldots \cdots
\end{aligned}
$$

$$
\begin{aligned}
\frac{d H_{e}}{d x}= & \frac{H_{e}}{\left(I_{3} I_{4} F d_{s}^{2}-I_{5} I_{6} F_{s}{ }^{2}-2 I_{7}\right)}\left\{\left(2 I_{3} I_{4} F d_{s}^{2}\right.\right. \\
& \left.-I_{5} I_{6} F_{s}{ }^{2}-I_{7}\right)\left(\frac{2 E_{h}}{I_{1} B_{e}}+\frac{E_{v}}{I_{2} H_{e}}\right) \\
& \left.-\left(I_{3} I_{4} F d_{s}^{2}-I_{5} I_{6} F_{s}{ }^{2}-I_{7}\right) \frac{1}{B_{e}} \frac{d B_{e}}{d x}\right\}
\end{aligned}
$$

$$
\frac{d \Delta \rho_{s}}{d x}=-\Delta \rho_{s}\left(\frac{2 E_{h}}{I_{1} B_{e}}+\frac{E_{v}}{I_{2} H_{e}}\right)
$$

ここに,

$$
\begin{aligned}
& I_{1}=\int_{-\infty}^{\infty} f_{1}(t) d t=\sqrt{\pi}, \quad I_{2}=\frac{I_{1}}{2}, \\
& I_{3}=\int_{-\infty}^{\infty} f_{1}^{2}(t) d t=\sqrt{\frac{\pi}{2}}, \quad I_{4}=\frac{I_{3}}{2}, \\
& I_{5}=\int_{-\infty}^{\infty} f_{1}^{2}(t) f_{2}(t) d t=\sqrt{\frac{2}{5} \pi}, \quad I_{6}=\frac{I_{5}}{2}, \\
& I_{7}=2.4533, \quad F d_{s}=\frac{U_{s}}{\sqrt{\left(\Delta \rho / \rho_{a}\right) g \cdot H_{e}}} \\
& \text { および } \quad F_{s}=\frac{U_{s}}{\sqrt{g H_{e}}}
\end{aligned}
$$

ただし，上式中の $F_{s}{ }^{2}$ に関連する項は式（6）中の密度 $\rho$ に起因するものであり，ブーシネスク近似した場合に

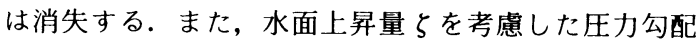
$d P / d x$ をそのまま $z$ 方向へ積分することは不可能であ るため, 次式のように Maclaurin 展開して $z=0 \sim 2 H_{e}$ の範囲で項別積分することにより係数值 $I_{7}$ を求めた.

$$
\begin{aligned}
\int_{0}^{2 H_{e}} & \int_{0}^{z / H_{e}} f_{2}(t) d t d z \\
& \doteqdot \int_{0}^{2 H_{e}}\left\{z-\frac{1}{6} z^{3}-\frac{1}{40} z^{5}-\frac{1}{366} z^{7}-\cdots\right\} d z
\end{aligned}
$$

以上の基礎方程式 (17) (19) が末知量 $U_{s}, \Delta \rho_{s}, B_{e}$ および $H_{e}$ を規定する方程式である．解を得るためには さらに横方向拡がり $B_{e}$ を記述する方程式を必要とする とともに， $E_{v}$ と $E_{h}$ を前もって設定しなければならな w.

\section{（3）浮力効果の表現}

方程式の数の不足を補うための付加的な条件のなかに 密度流固有の浮力効果を導入せざるを得ない点が積分モ デルの特色であると同時に欠点でもある. 本論文では, 実験結果に基づいて浮力効果を（i ）下層からの連行率 の低減と, ( ii )横方向拡がりの促進の二面から検討する.

鉛直方向連行係数 $E_{v}$ は Ellison・Turner 流に成層度 の指標であるリチャードソン数 $R i$ の関数で表現され る.ここでは, 次式で示す Koh ${ }^{15)}$ の実験式を採用する.

$$
E_{v}=\frac{V_{e}}{\bar{U}}=E_{0}\left(\frac{2}{1+\bar{R} i / 0.85}-1\right)^{1.75}
$$

ここに， $E_{0}$ は均質噴流における連行係数であり, 一般 に0.075 の值が用いられる.

Ellison・Turner および Koh の実験の妥当性に関し ては種々議論があったが, 著者らの二次元水理実験 ${ }^{2}$ に おいてその妥当性は検証されている. しかしながら, 式 （22）は断面平均した水理量を用いて表示されており, 本解析への適用に際しては $E_{0}$ および $R i$ を換算して用 いる必要がある. 流速および密度差の鉛直方向分布より $H=1.75 H_{e}, \bar{U}=0.497 U_{s}$ および $\overline{\Delta \rho}=0.664 \Delta \rho_{s}$ と求 められることより, 式 $(22)$ の $E_{0}$ の值は 0.0375 に, また $\overline{R i}$ は $R i_{s}$ の 4.61 倍となる.

一方, 横方向拡がり率 $d B / d x$ と成層度との関係につ いては明確な表現はない。水表面における流動形態の可 視化観測から浮力効果は拡がり率の増分に直接的な影響 を及ぼす”ことがわかったので，本解析ではPrych らが 用いている密度流塊の拡がり速度による評価法を採用す る.

$\mathrm{Koh}^{16)}$ は図一2 に示すような周囲環境水 $\rho_{a}$ と $\Delta \rho$ の密 度差を有した流体が静止水域を拡がってゆく現象を定式 化している．挔がりを支配する要因のうち慣性力とせん 断抵抗が省略でき, 密度差による圧力と抗力がつり合っ ている拡がり現象の中間段階を考えると, 


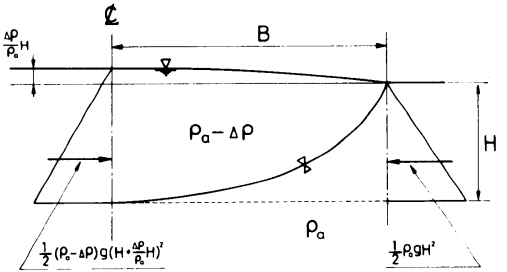

図一2 横方向拡がり速度の説明図 ${ }^{16)}$

$\frac{1}{2} g \cdot \Delta \rho H^{2}=C_{D} \rho_{a} \frac{H}{2}\left(\frac{d B}{d t}\right)^{2}$

となる.ここに， $C_{D}$ は抗力係数である. 上式を変形す ることにより, 密度流塊の拡がり速度を与える次式が得 られる.

$$
\frac{d B}{d t} \sim \sqrt{\frac{\Delta \rho}{\rho_{a}} g H}=c_{1} \sqrt{\frac{\Delta \rho}{\rho_{a}} g H}
$$

この拡がり速度が浮力のみによる拡がり幅 $B_{b}$ をうまく

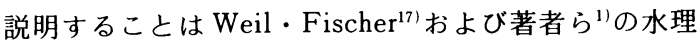
実験によって確認されている，そこで，放流水束が噴流 外縁に直交する方向に $d B / d x$ の拡がり速度で拡大する と同時に, 流下方向に流速 $U$ で移流すると仮定すれば, 密度差に原因する横方向拡がり率 $(d B / d x)_{\text {。 }}$ は単純な 幾何学的特性からPrych の提案式"'亡同様の次式で表わ される.ただし，式（23）の $c_{1}$ は密度流塊の先端の形 状により決まる係数であり，ここでは 1.0 とした。

$$
\left(\frac{d B}{d x}\right)_{b}=\frac{1}{\sqrt{2}} \frac{1}{\sqrt{F d_{s}^{2}-1}}
$$

いま, $(d B / d x)_{n b}$ として, Tollmien ${ }^{18)}$ の値 0.115 を $B_{e}$ に換算した值 0.138 を採用するとすれば，拡がり率 $d B / d x$ は 0.138 と式 (24) の和として表現される.

\section{4. 数值解析法と初期条件の設定}

数値計算は式 (17)，(18)，(19）および式（1)，(24） を基礎方程式として Runge ・ Kutta の数値積分法により 行う.

しかしながら，積分モデルは流速と密度差の分布形が ともに自己相似性を満たす流動に対してのみ適用される ので,密度噴流の形成・遷移領域の取扱いが重要となる. すなわち, 形成・遷移領域の終端点での水理諸量を数值 解析の初期値として特定する必要がある. 実験的興味が 自己相似性の成立する流れの確立領域にあったために, この領域での流動を詳細に実測した研究は少ない. 本解 析ではStefan et al. ${ }^{199}$ の実験結果に基づいて初期条件を 設定する. 形成・遷移領域での水理量を図一3に模式的 に示す.

\section{（1）形成・還移領域の長さ}

Stefan et al. に倣い, 噴流軸上の密度差 $\Delta \rho$ が初期
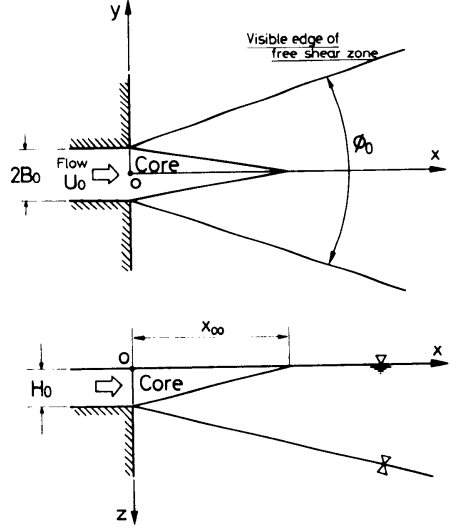

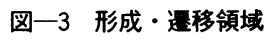

密度差 $\Delta \rho_{0}$ の $90 \%$ となる位置で形成・遷移領域の最終 点 $x_{00}$ を定義すると, $x_{00}$ は初期密度フルード数 $F d_{0}$ お よび形状比 $A$ の関数として次の実験式で与えられる.

$$
\frac{x_{00}}{H_{0}}=6.05 A^{0.46}\left\{1-\frac{0.5 F d_{0}-1.5}{\exp \left(0.4 F d_{0}\right)}\right\}
$$

ここに, $A=2 B_{0} / H_{0}, F d_{0}=U_{0} / \sqrt{\left(\Delta \rho_{0} / \rho_{a}\right) g H_{0}}$ であり, 適用範囲は $1.0<A<9.6,2.0<F d_{0}<15$ である.

\section{（2）形成・遝移領域終端点での拡がり幅}

水表面上のトレーサーの可視観測より, 横方向拡がり 角度 $\phi_{0}$ は $F d_{0}$ の関数として次式で与えられる.

$$
\phi_{0}=\frac{225+10 F d_{0}}{2.25+F d_{0}} \text { for } F d_{0}>1.0
$$

したがって，終端点での拡がり幅 $B_{00}$ は $\phi_{0}$ を用いて

$$
B_{00}=\tan \left(\frac{\phi_{0}}{2}\right) \cdot x_{00}+B_{0}
$$

となる． $B_{00}$ は実測值との比較から nominal boundary に対応していることがわかっている. よって, 終端点で 流速分布が式( 3 )，（４）で関数表示されると仮定すると， 流速が $U_{s}$ の $1 / e$ となる特性幅 $B_{e_{00}}$ は次式で求まる.

$$
B_{e_{00}}=B_{00} / 1.98 \text {. }
$$

\section{（3）流速と密度差の初期值}

$x_{00}$ の定義で $\Delta \rho_{0}$ の $90 \%$ 值を初期值に設定したが, $x_{00}$ での流速値は $90 \%$ より少し下回るようである. 実験 ケースにより多少散乱気味であることから, 本解析では $0.85 U_{0}$ を初期值として特定する.

\section{（4）喷流水深の初期值}

流下距離 $x$ における流量 $Q$ は $F d_{0}$ と $A$ の関数とし て実験から次のように求まる.

$$
\frac{Q}{Q_{0}}=1+\left\{0.087\left(\frac{x}{2 H_{0}}\right)^{\frac{2.35+0.751}{0.90+1}}\right\} \times\left(1-\frac{0.52}{F d_{0}^{0.41}}\right)
$$

また，流速分布が式（3），（4）で与えられる場合には, 
流量 $Q$ は積分することにより，

$$
Q=U_{s} \int_{0}^{\infty} \int_{-\infty}^{\infty} f_{1}\left(\frac{y}{B_{e}}\right) \cdot f_{1}\left(\frac{z}{H_{e}}\right) d y d z=\frac{\pi}{2} U_{s} B_{e} H_{e}
$$

となる. 式 $(28)$ と式 $(29)$ より噴流水深 $H_{e}$ は次式の ように求まる.

$$
\begin{aligned}
H_{e_{00}}= & {\left[1+\left\{0.087\left(\frac{x_{00}}{2 H_{0}}\right)^{\frac{2.35+0.75 A}{0.90+A}}\right\}\right.} \\
& \left.\times\left(1-\frac{0.52}{F d_{0}^{0.41}}\right)\right] \frac{4}{\pi} \cdot \frac{B_{0} H_{0}}{0.85 B_{e_{00}}}
\end{aligned}
$$

以上で, 数値計算のための初期值がすべて求まった.

\section{5. 数値解析結果と実験値との比較}

比較した実験值は温排水の放流を対象に著者らが実施 したもの 1 であり, 流速および密度差の分布形が式 ( 3 ), (4) で近似できることが確認されている. また，Fd。 の値は 3〜8の範囲である.

図一 4 と 5 はそれぞれ流速 $U$ および密度差 $\Delta \rho$ の莪 减特性を慣用的な表示で示したものである，図の上側が 解析結果，下側が実験結果である．解析解之実験值の莪 減特性はほぼ良好に一致しているのがわかる. 密度フ ルード数の小さいほど, また流下距離が進むほど, 流速 の莪減の度合はゆるやかになる，莪減率は放流口近傍で は均質噴流の-1 乗則に近いが, 流下に伴い平面噴流の -1/2 乗則に近づいている. すなわち, 流下するに伴い, 浮力による重力安定効果によって平面噴流的な挙動に移

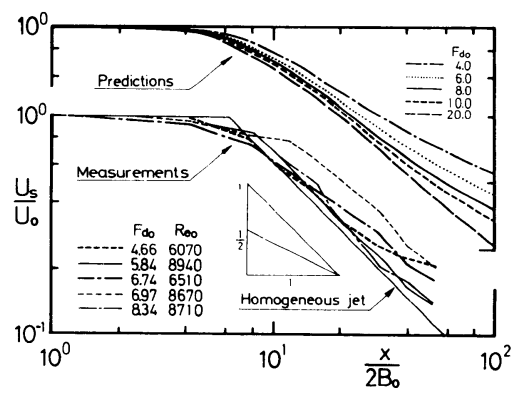

図一4 流速の旡減特性

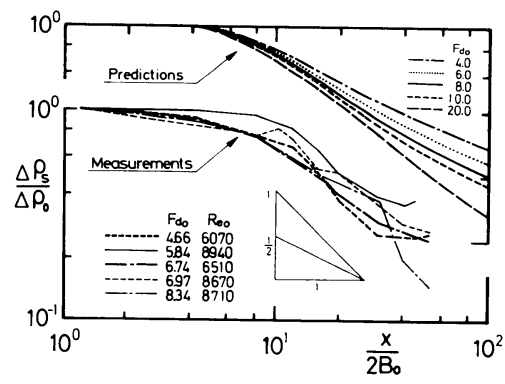

図一5 密度差の瓝娍特性

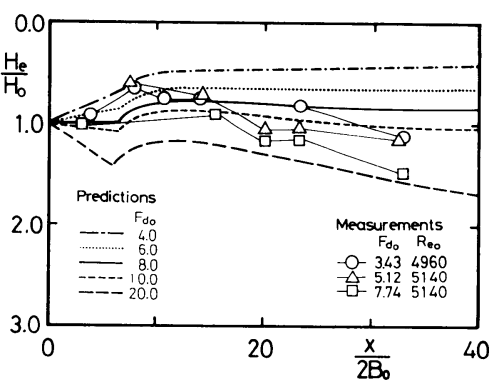

图一流水深の流下方向変化

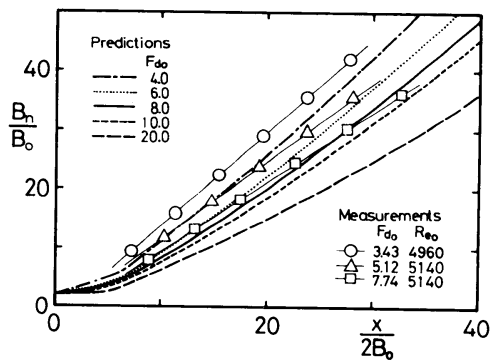

図一7 喷流幅の流下方向変化

り変わる様子が解析と実験の両結果から確認できる.同 様の傾向が密度差 $\Delta \rho$ の逓減特性にも現われている.

図-6 は流速が $U_{s}$ の $1.0 / e$ となる水深で定義される 噴流水深 $H_{e}$ を示す，また，図一7は $U_{s}$ の $2 \%$ となる 位置で定義される噴流幅 $B_{n}$ (nominal boundary) を示 す. 図中の印は $F d_{0}=3.43,5.12,7.74$ の実験值である. 解析結果は鉛直方向の挔がりをやや過小評価するもの の, 全体として重力安定効果により拡がりの抑制される 点がうまく表現できている. また，横方向への拡がりは 実験結果と良好に一致しており，表層密度噴流の横方向 への拡がりを水表面上の密度流塊の拡がり速度で表現す ることの妥当性が検証できた。

\section{6. 数値解析結果と実測値との比較}

Michigan 湖の Point Beach 原子力発電所からの温排 水を対象にArgonne 国立研究所で実施された現地観測 は詳細に行われており, 信頼性の高いものである ${ }^{20)}$. こで, 多数の実測結果のなかで静穏な周囲環境のもとで 得られた結果を選び，解析結果との比較を行う。また， 同時に2. で記述した主要な 5 つの積分モデルによる解 析結果との競合も行う. 図一8～13 は文献 20）から引用 したものであり，本論文の解析結果を記入して示す.

\section{（1）数值解析例一1}

図一8〜11は 1972 年 3 月 23 日に静穏な周囲環境条件 のもとで得られた実測結果と解析結果とを比較したもの である.太い実線が今回実施した解析結果である。他の 
表一2 数值解析に用いた実測データ

\begin{tabular}{|c|c|c|}
\hline 水 理 条 件 & $\begin{array}{c}1972 \text { 年 } \\
3 \text { 月 } 23 \text { 日 }\end{array}$ & $\begin{array}{l}1972 \text { 年 } 5 \text { 月 } \\
\text { 平 均值 }\end{array}$ \\
\hline 放 出 流 速 $U_{0}(\mathrm{~cm} / \mathrm{s})$ & 55.5 & 56.0 \\
\hline 放流口幅 $2 B(\mathrm{~m})$ & 10.7 & 10.7 \\
\hline 放流口水深 $H(\mathrm{~m})$ & 4.2 & 4.2 \\
\hline 放流水温度 $\theta_{0}\left({ }^{\circ} \mathrm{C}\right)$ & 21.6 & 20.5 \\
\hline 周囲水温度 $\theta_{a}\left({ }^{\circ} \mathrm{C}\right)$ & 14.3 & 10.8 \\
\hline 周囲水流速 $U_{a}(\mathrm{~cm} / \mathrm{s})$ & 0.0 & 0.0 \\
\hline 密度フルード数 $F d_{0}$ & 2.37 & 2.24 \\
\hline
\end{tabular}

曲線は Argonne 国立研究所で実施された $5 つ$ つ積分モ デルによる解析結果である. 解析に用いた水理条件は表 -2 の第 2 項に示すとおりである.

図一8は噴流軸上の流速の莪减特性を示す，実測によ ると $x / 2 B_{0}=5.0$ 付近までの範囲で流速が放出流速 $U_{0}$ より加速されていることから, 今回の解析では形成・遷 移領域内では流速は低減しないものと, モデルを修正し て計算した。 太い実線で示す解析結果と実測值は非常に よく一致しており, 流速の违減特性をうまく予測してい る.

図一 9 は温度差 $\Delta \theta_{s}$ の逓減特性を示す，温度差は計算 した密度差を換算して求めた。解析解は流下距離の短い

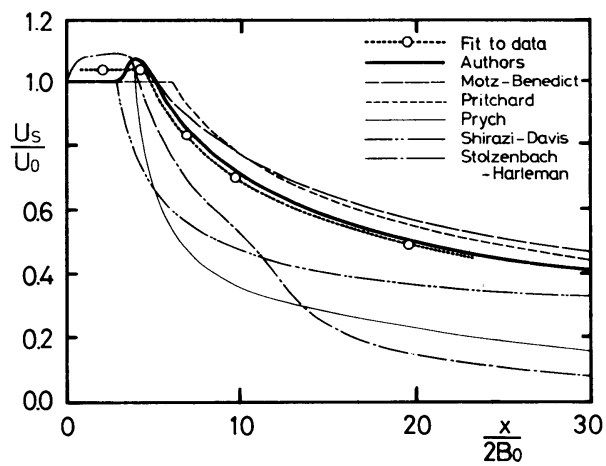

図一8 流速の适娍特性

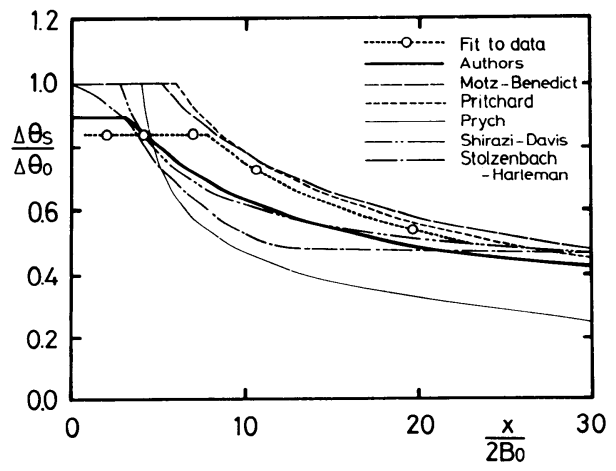

図一9 温度差の逘娍特性 $x / 2 B_{0}<20$ の範囲では実測値よりも小さな值となるが, 流下するにつれて実測値に漸近してゆくようである.

図一10，11 は流速および温度差の半值半幅， $B_{0.5}$ と $B_{0.5}$ の流下方向変化を示す. 解析解は流下するにつ れて拡がりをやや過大評価する傾向にあるものの, 他の 積分モデルの予測値と比較して遜色のない結果をもたら している.

総合的に評価した場合，提案モデルの解析結果は既発 表の主要な $5 つ の$ 積分モデルと比較しても実測結果を良 好に予测する部類に属していると結論できる.

提案モデルと同程度に良好に実測結果を予測している のは 5 つのモデルのうち Pritchard のモデルであるが, これはモデルと現地実測あるいは水理実験の結果とを丹 念に比較検証してモデルを構築したことによる．彼の疑 似三次元モデルあるいは Motz・Benedict の二次元モデ ルが流速および温度差の莪减特性を比較的うまく予測し ていることを考え合わせると, 放出水束は比較的短い流 下位置から浮力による重力安定効果を受けて成層流的な 挙動に遷移しているものと推察される.

Stolzenbach ・ Harleman および Prych の解析結果は 横方向拡がりをかなり過大評価している，拡がり速度に せん断抵抗を考虑することによりPrych モデルを修正 した，Shirazi ・ Davis モデルでは横方向拡がりを少し

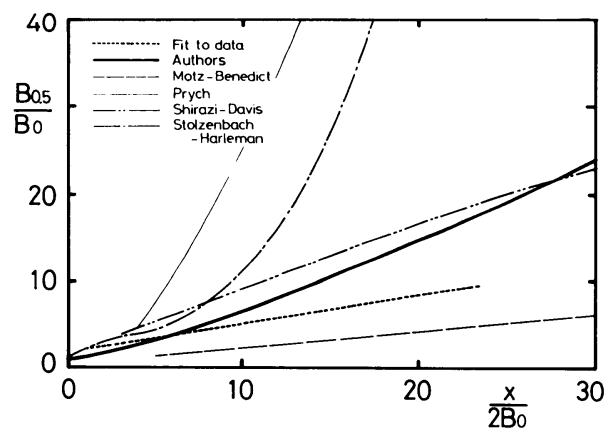

図一10 流速の半值半湢の流下方向变化

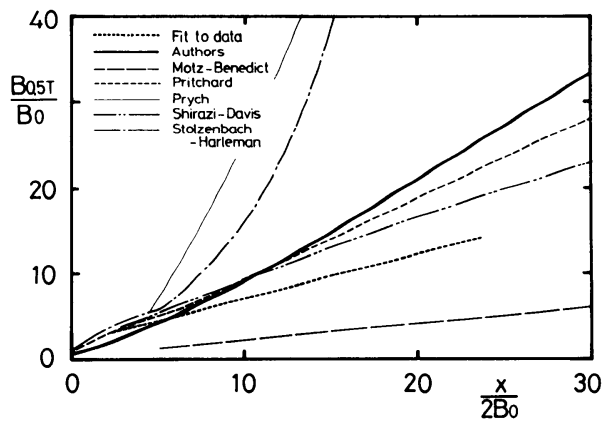

图一11 温度差の半值半幅の流下方向変化 
良好なものとしたが，噴流軸上流速の急激な低減は改良 されていない. Prych あるいは Shirazi・Davis の横方 向拡がり率の定式化は提案モデルと同形である. 解析結 果の相違は ( i ) 流速と温度差の相似分布形の違い, ( ii ) 形成・遷移領域の取扱いの違い, (iii) 下層からの連行 率や横方向拡がり速度の表現法の不統一, 等に原因して いる. 数值解析の実行に際しては（iii）の影響は見逃せ ない. 関数表示に用いられる水理量の定義が提案者によ り多種多様であり,これらが混同されて採用された場合 には過剩な連行あるいは過大な拡がりを招いたり, 数值 解の安定性を脅かす原因にもなりかねない.

\section{（2）数值解析例一2}

Argonne 国立研究所で 1972 年 5 月に 4 回にわたって 実施された実測は, 既発表の積分モデルのうち現象を良 好に説明するとみなされたPritchard とShirazi ・ Davis のモデルを検証する目的で行われた。.そのときの周囲環 境条件の平均値を表一2の第 3 項に示す.

図一12 は噴流軸上の水表面温度差 $\Delta \theta_{s}$ の流下方向連 減特性を示す. 図中の符号は 4 回の実測値を示し, 曲線 は解析解を示す. 図一9 と同様に, 解析結果は放流口近 傍で実測值よりも少し小さな值を示すが, $x / 2 B_{0}>40$ と流下するに伴って解析解は実測值に近づいてゆく傾向 にある. 温度差の莪減に関していえば, 提案モデルと Shirazi・Davis のモデルはほぼ同様の傾向を示してお り, Pritchard モデルの逓減率は相対的に大きい.

図一13 は温度差の半値半幅 $B_{0.5 T}$ の流下方向変化を示

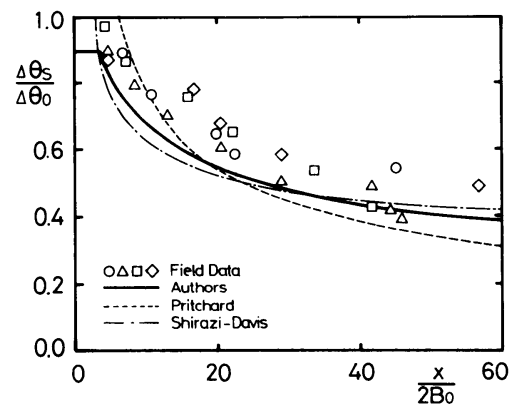

図一12 温度差の魀娍特性

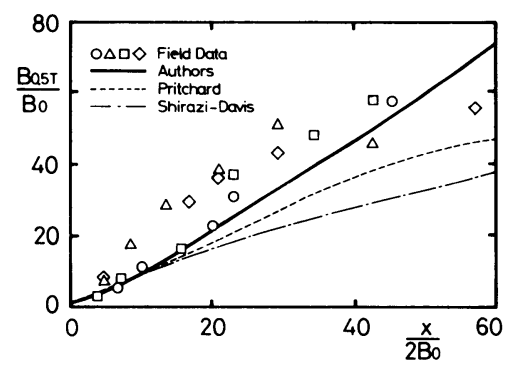

图一13 温度差の半值半幅の流下方向变化
す. 提案モデルは実験結果を良好に予測するのに対して， 他のモデルは相当過小評価する傾向にある. また, 図一 13 の結果は図一11における解析結果と実測結果との関 係とは全く逆の傾向を示しているが，それは図一11に 示された実測値の拡がりが少し小さかったためであると 予想される. 実測は $x / 2 B_{0}=150$ の遠方領域まで実施 されていたが, 近接領域を除いては沿岸地形の影響を受 けて実測精度が疑わしいので, 検証は $x / 2 B_{0}<60$ の範 囲にとどめた。図一12 および図一13 の比較より, 表層 密度噴流の近接領域における流動に対する提案モデルの 適合性が検証されたといえる.

\section{7. 結語}

三次元表層密度噴流の近接領域での流動を予測するた めの積分モデルを基礎的な水理実験で得られた知見に基 づいて構築し，その適合性を水理実験および現地実測結 果との比較より検討した. 本研究で得られた結論を列挙 すると次のようになる.

（1）積分モデルでは付加的な条件のなかに浮力効果 をいかに適切に導入するかが肝要である. 提案モデルで は, （ｉ）下層からの連行率の莪减をKoh の実験式を用 いて, また（ii）横方向拡がりの促進を密度流塊の拡が り速度を用いて記述した. 両効果はともに密度フルード 数の関数で表現されることが水理実験より確認されてい る.

（2）ただし，上記関数関係を採用するに際しては, 流速あるいは密度の分布形を勘案して, 関数表示に用い られている水理量に換算する必要がある。（ｉ）と（ii） は表裏の関係にあり, 両者のバランスを欠いた場合には 下層からの過剩な連行や過大な横方向の拡がりを招き, 数値計算の安定性が脅かされる結果となる.

（3）提案モデルによる解析結果を水理実験ならびに Point Beach 原子力発電所からの温排水の放流に対する 現地実測と比較検討した結果, 提案モデルは全体として 近接領域の流動を良好に予測し得ることが検証できた. また, 既発表の代表的な 5 つの積分モデルとの比較にお いても, 提案モデルが最も優れていることがわかった.

（4）積分モデルは流速および密度分布形の相似性を 前提としているが, 断面積分値が分布形状にそれほど依 存しないことから, 工学的な目的のためには積分モデル は有用であろう.ただし，本論文の提案モデルは静皧な 沿岸海域への温排水の拡がりを対象にしたものである. 現実には, 沿岸海域の流れ, 乱れあるいは成層化, およ び水表面での熱交換等種々の要因が相乗し合って, 現象 は複雑な様相を呈している.これらの要因の多くは積分 モデルの中に線形に組み込むことが可能であり, 積分モ デルを拡張して適用できる. 


\section{参 考 文 献}

1) Murota, A., Muraoka, K. and Nakatsuji, K. : Initial Entrainment and Lateral Spread of Three-dimensional Buoyant Surface Jet, J. Hydroscience and Hydr. Eng., Vol. 1, No. 2, pp. 33 51, 1983.

2）室田 明・中辻啓二：二次元表層密度噴流における連行 特性に関する研究, 土木学会論文集, 第 351 号/ II - 2, pp. $97 \sim 106,1984$.

3）室田 明・中辻啓二・柴垣雄一：沿岸域での表層放流水 束に及ぼす浮力効果について, 第 28 回水理講演会論文集, pp. 113 119, 1984.

4) Dunn, W. E., Policastro, A. J. and Paddock, R. A. : Surface Thermal Plumes : Evaluation of Mathematical Models for the Near and Completed Field. Part 1 and 2, Argonne National Labo., ANL/WR-75-3, 1975.

5) Motz, L. H. and Benedict, B. A. : Heated Surface Jet Discharged into a Flowing Ambient Stream, Rept. No. 4, Dept. of Environ. and Water Resour., Vanderbilt Univ., 1970.

6) Pritchard, D. W. : Design and Siting Criteria for Oncethrough Cooling Systems, American Institute of Chemical Engineers, 68 th Annual Meeting, Houston, 1971.

7) Ellison, T.H. and Turner, J.S. : Turbulent Entrainment in Stratified Flows, J. Fluid Mech., Vol. 6, pp. 423 448, 1959.

8) Stefan, H. and Vaidyaraman, P. : Jet Type Model for the Three-Dimensional Thermal Plume in a Crosscurrent and under Wind, Water Resour. Res., Vol. 8, No.4, pp. 998 1014, 1972

9) Prych, E. : A Warm Water Effluent Analyzed as a Buoyant Surface Jet, Swedish Metheological Institute, Rept. No. 21, Stockholm, 1972.

10) Shirazi, M. and Davis, L. : Workbook of Thermal Plume Prediction, Vol.2, Surface Discharge, Pacific Northwest Environ. Res. Labo., Rept. EPA-R 2-
72-005 b, 1974 .

11) Stolzenbach, K. and Harleman, D. R.F. : An Analytical and Experimental Investigation of Surface Discharge of Heated Water, Ralph M. Parsons Labo., MIT, Rept. No. 135, 1971.

12）林 泰造・有田正光：温度密度流の拡がりに関する予測 モデルの研究, 第 20 回水理講演会論文集, pp. 161 172, 1976.

13）椿東一郎・小松利光：3 次元表層密度噴流について, 第 22 回水理講演会論文集, pp. 1 6, 1978.

14) Engelund, F. and Pederson, F. B. : Surface Jet with Small Richardson Numbers, Proc., ASCE, Vol. 99, HY 3, pp. 405 416, 1973.

15) Koh, R.C.Y. : Two-Dimensional Surface Warm Jets, Proc. ASCE, Vol. 97, HY 6, pp.819 836, 1971.

16) Koh, R. C. Y. : Buoyancy-Driven Gravitational Spread ing, Proc. 15 th Coastal Eng. Confer., pp. 2956 2975, 1976.

17) Weil, J. and Fischer, H. B. : Effect of Stream Turbu lence on Heater Water Plumes, Proc. ASCE, Vol. 100, HY 7, pp. 951 970, 1974.

18) Tollmien, W. : Berehnung Turbulenter Ausbreitungsvorgänge, ZAMM, Vol.6, pp. 468 478, 1926.

19) Stefan, H., Bergstedt, L. and Mrosla, E. : Flow Establishment and Initial Entrainment of Heated Water Surface Jets, St. Anthony Falls Hydr. Labo., Univ. of Minnesota, EPA-660/3-75-014, 1975.

20) Paddock, R.A., Policastro, A. J., Dunn, W. E. and Kyser, J.M. : Application of Prominent Near-field Models for Heated Surface Discharges to Prototype Field Data on Lake Michigan, U. S. - Japan Seminar on Eng. and Environ. Aspects of Waste Heat Disposal, 1974.

(1984.4.6 - 受付） 